\title{
Spinocerebellar ataxia type 10 in the South of Brazil: the Amerindian-Belgian connection
}

\author{
Ataxia espinocerebelar tipo 10 no sul do Brasil: a conexão Ameríndia-Belga \\ Hélio Afonso Ghizoni Teive', Adriana Moro', Mariana Moscovich', Walter Oleskho Arruda', Renato Puppi \\ Munhoz ${ }^{2}$, Salmo Raskin³, Gladys Mary Ghizoni Teive ${ }^{4}$, Norberto Dallabrida ${ }^{4}$, Tetsuo Ashizawa ${ }^{5}$
}

\begin{abstract}
Spinocerebellar ataxia type 10 (SCA10) is a rare form of autosomal dominant ataxia found predominantly in patients from Latin America with Amerindian ancestry. The authors report the history of SCA10 families from the south of Brazil (the states of Paraná and Santa Catarina), emphasizing the Belgian-Amerindian connection.
\end{abstract}

Keywords: cerebellar ataxia, spinocerebellar ataxia, SCA10, Amerindians, Belgians, history.

RESUMO

A ataxia espinocerebellar tipo 10 (AEC10) é uma forma rara de ataxia cerebelar autossômica dominante, encontrada predominantemente em pacientes da América Latina, de origem Ameríndia. Os autores relatam a história de famílias com AEC10 do sul do Brasil (estados do Paraná e Santa Catarina), enfatizando a conexão Ameríndia-Belga.

Palavras-chave: ataxia cerebelar, ataxia espinocerebellar, AEC10, ameríndios, belgas, historia.

Spinocerebellar ataxia type 10 (SCA10) is a rare form of autosomal dominant cerebellar ataxia found predominantly in patients from Latin America with Amerindian ancestry ${ }^{1}$. The condition is caused by the expansion of a non-coding pentanucleotide repeat (ATTCT) within intron 9 of the ataxin 10 (ATXN10) gene on chromosome 22q13.1,2,3. SCA10 was originally described in Mexican patients with a clinical picture characterized by cerebellar ataxia, including gait and limb ataxia, dysarthria and ocular abnormalities, together with extracerebellar involvement, particularly seizures $^{3}$. A study of Mexican patients found that $72.2 \%$ of the study population had epileptic seizures (ranging from 25 to $80 \%$ ), which presented as generalized motor seizures and/or complex partial seizures ${ }^{3}$. In contrast to these patients, our Brazilian series of SCA10 patients predominantly showed a "pure" cerebellar ataxia, which is in some cases presented with mild pyramidal signs ${ }^{2}$. Another study confirmed the low frequency of epilepsy (3.75\%) in Brazilian
SCA10 patients ${ }^{4}$ SCA10 has also been found in patients from Argentina, Venezuela, Colombia, Bolivia, USA, and, recently, Peru. Like the Mexican SCA10 patients, these patients from Argentina, Venezuela, Colombia, Bolivia, and Peru presented with epileptic seizures ${ }^{1,5}$. In 2013, de Castilhos et al. published a study of SCAs in Brazil, in which they investigated the frequency of the disease and the effect of modulation by related genes ${ }^{6}$. They studied 544 SCA patients from 359 families in 11 Brazilian cities and found SCA10 in 12 families (3.3\% of the cases). Interestingly, they found that $64.7 \%$ of their SCA10 patients exhibited seizures ${ }^{6}$. Interruptions of the ATTCT repeat expansions may be a disease modifier that could explain the phenotypic differences between these SCA10 patients ${ }^{7}$. This hypothesis is supported by extensive data published by McFarland et al., who concluded that the presence of repeat interruptions in SCA10 repeat expansions indicates a significant risk for the epilepsy phenotype ${ }^{7}$. Historically, several studies support the hypothesis that the

¿Universidade Federal do Paraná, Hospital de Clínicas, Departamento de Medicina Interna, Serviço de Neurologia, Universidade de Distúrbios do Movimento, Curitiba PR, Brazil;

${ }^{2}$ University of Toronto, Movement Disorders Centre, Toronto, Canada;

${ }^{3}$ Laboratório Genetika, Curitiba PR, Brazil;

«Universidade Estadual de Santa Catarina, Centro de Ciências Humanas e Educação, Florianopolis SC, Brazil;

5 University of Florida, Department of Neurology, Mc Knight Brain Institute, Gainesville FL, USA.

Correspondence: Hélio Afonso Ghizoni Teive; Rua General Carneiro, 1103/102; 80060-150 Curitiba PR, Brasil; E-mail: hagteive@mps.com.br

Conflict of interest: There is no conflict of interest to declare.

Support: NIH grant NS083564 to Tetsuo Ashizawa.

Received 14 December 2014; Received in final form 28 March 2015; Accepted 16 April 2015. 
ancestors of Amerindians and Native Americans migrated from eastern central Asia across the exposed Bering land bridge to North America and then spread to Central and South America 5 .

\section{SPINOCEREBELLAR ATAXIA TYPE 10 IN THE SOUTH OF BRAZIL (THE STATES OF PARANÁ AND SANTA CATARINA)}

To date, we have studied more than 200 families with SCAs and have found 14 families (90 patients) with SCA type 10 living in the states of Paraná and Santa Catarina (in the south of Brazil). Of these patients with SCA10, only six (6.6\%) presented with epilepsy and according to their oral history, most of them were of Amerindian descent. Almeida et al. studied the ancestral origin of the ATTCT repeat expansion in SCA10 and concluded that there is a common ancestral origin in Latin America for this disease, which may have arisen in an ancestral Amerindian population and later spread to the mixed population of Mexico, Brazil and probably other Latin American countries ${ }^{8}$. Our assessment of our series of SCA10 patients, most of whom were from the state of Santa Catarina, revealed that the families had their origins mainly in the coastal areas of the state, between the cities of São Francisco do Sul and Florianópolis. However, the ancestry of $62.5 \%$ of the families could be traced back to the town of Ilhota in the lower Itajaí Valley, state of Santa Catarina. (Figure) In this same area already occupied by Xokleng Indians, were later populated by European immigrants, such us Belgian, German and also Azorean-Portuguese immigrants ${ }^{9,10}$.

\section{THE AMERINDIAN-BELGIAN CONNECTION}

The town of Ilhota, SC, in the lower Itajaí Valley, has an unusual history as it was the destination of Belgian immigrants in the $19^{\text {th }}$ century9. The Flemish colony in the town of Ilhota in Santa Catarina was described in a book by Maes published in 2005. In 1844 a group of Belgians led by Charles Van Lede immigrated to Ilhota. A Belgian-Brazilian company was established to operate primarily in mining in the region between the Itajaí-Açu and Itajaí-Mirim rivers. The "Belgian Colony" experienced periods of prosperity and failure, with countless quarrels and disagreements between the settlers, and in 1889 the population stood at four hundred families, one third of whom were of Belgian descent and the remainder Brazilian'. At that time the state of Santa Catarina had a significant indigenous population, particularly Indians who spoke the Jê language, such as the Xokleng, or botocudos, as they were better known (Figure). Other indigenous groups on the Santa Catarina coast included the Tupis-Guaranis (known as the carijos) and the

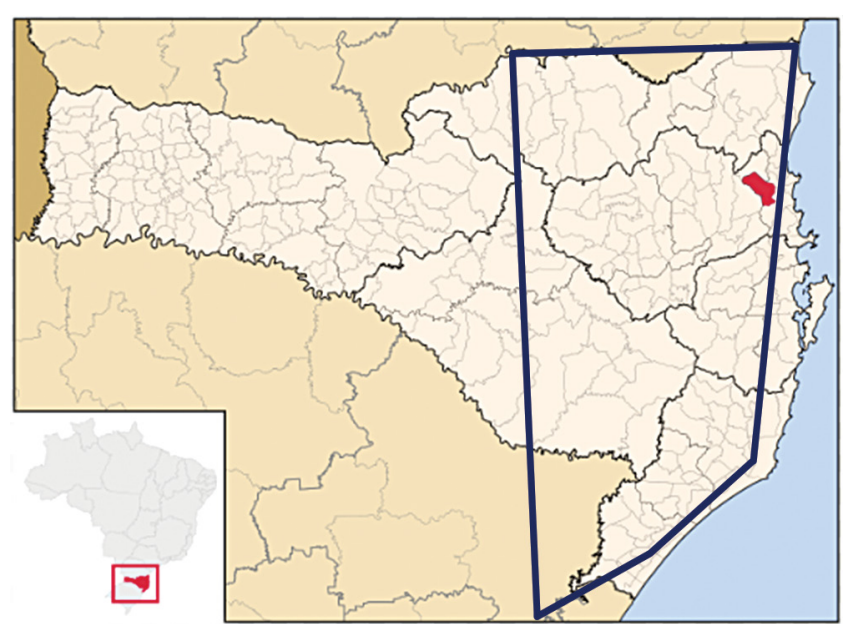

(Adapted from Google maps - October, 04, 2014)

Figure. Santa Catarina State, Ilhota town (red) and historical area of Xokleng's Indians (blue line).

Kaingang, who were spread along the coast and the Santa Catarina plateau ${ }^{10}$. In the Itajaí Valley region, between the towns of Ilhota and Blumenau, the main indigenous group was the Xokleng, who were almost completely wiped out in conflicts with the German population ${ }^{10}$. Some descendants of the Xokleng, particularly females, were sent to Catholic schools to be educated and to learn to read and write, and others were taken in by families of German descent ${ }^{10}$. An example of the latter was the well-known case of the doctor of German descent, Dr. Hugo Gensch, who adopted the Indian girl Korikrã, who was later to become "Miss Gensch"10. Three of the SCA10 families whose origins can be traced to the town of Ilhota each independently confirmed an interesting story going back to their great-grandfathers, according to which the families' were descended from an interracial marriage between a Belgian patriarch and a lady of indigenous descent. After the wife of one of the original settlers in the "Belgian Colony" in Ilhota died from infection, her widower married his employee, who was of indigenous origin, and together they had twenty-one children. It is reasonable to suppose that SCA10 spread in the region after these families migrated from the town of Ilhota to neighboring towns. An interesting question to study is whether this Amerindian/Belgian connection has any influence on the phenotype observed in most of the SCA10 patients from this region. In addition, the absence of repeat interruptions in SCA10 repeat expansion might be the cause of the phenotype of pure cerebellar ataxia without epilepsy?

\section{Acknowledgments}

The authors would like to thank the relatives of the SCA10 families for providing historical information about their families. 


\section{References}

1. Teive HAG, Munhoz RP, Arruda WO, Raskin S, Werneck LC, Ashizawa T. Spinocerebellar ataxia type 10: a review. Parkinsonism Relat Disord. 2011;17(9): 655-61. http://dx.doi.org/10.1016/j.parkreldis.2011.04.001

2. Teive HAG, Roa BB, Raskin S, Fang P, Arruda WO, Correa Neto Y. et al. Clinical phenotype of Brazilian families with spinocerebellar ataxia 10. Neurology. 2004;63(8):1509-12. http://dx.doi.org/10.1212/01.WNL.0000142109.62056.57

3. Rasmussen A, Matsuura T, Ruano L, Yescas P, Ochoa A, Ashizawa T et al. Clinical and genetic analysis of four Mexican families with spinocerebellar ataxia type 10. Ann Neurol. 2001;50:234-9. http://dx.doi.org/10.1002/ana.1081

4. Teive HAG, Munhoz RP, Raskin S, Arruda WO, Paola L, Werneck LC et al. Spinocerebellar ataxia type 10: frequency of epilepsy in a large sample of Brazilian patients. Mov Disord. 2010;25(16):2875-8. http://dx.doi.org/10.1002/mds.23324

5. Leonardi L, Marcotulli C, McFarland KN, Tessa A, DiFabio R, Santorelli FM et al. Spinocerebellar ataxia type 10 in Peru: the missing link in the Amerindian origin of the disease. J Neurol. 2014;261(9):1691-4. http://dx.doi.org/10.1007/s00415-014-7394-8

6. Castilhos RM, Furtado GV, Gheno TC, Schaefer P, Russo A, Barsottini $O$ et al. Spinocerebellar ataxias in Brazil: frequencies and modulating effects of related genes. Cerebellum. 2014;13(1):17-28. http://dx.doi.org/10.1007/s12311-013-0510-y

7. McFarland KN, Liu J, Landrian I, Zeng D, Raskin S, Moscovich M et al. Repeat interruptions in spinocerebellar ataxia type 10 expansions are strongly associated with epileptic seizures. Neurogenetics. 2014;15(1):59-64. http://dx.doi.org/10.1007/s10048-013-0385-6

8. Almeida T, Alonso I, Martins S, Ramos eM, Azevedo L, Ohno $\mathrm{K}$ et al. Ancestral origin of the ATTCT repeat expansion in spinocerebellar ataxia type 10 (SCA10). PLoS One. 2009;4(2):e4553. http://dx.doi.org/10.1371/journal.pone.0004553

9. Maes PR. Colonização flamenga em Santa Catarina - Ithota. Itajaí: Editora do Autor; 2005.

10. Wittmam LT. O vapor e o botoque. Florianópolis: Letras Contemporâneas; 2007 